\title{
A LITERATURE REVIEW ON URBAN SPRAWL IN DEVELOPED AND DEVELOPING COUNTRIES
}

\author{
Siva Kumar T. Renu' ${ }^{1 *}$, Tuan Pah Rokiah Syed Hussain ${ }^{2}$
}

\section{*Corresponding Author: -}

\begin{abstract}
: -
The urban sprawl is the process of a city that evolves from a high density center to form a low density area towards its periphery based on its own phases involving the historical outbreak of a city. The shape, process and effect of a urban sprawl are different. Therefore, studies related to the urban sprawl need to be carried out for each different city, even in the same country. Experience in developed and developing countries suggests that any urban sprawl have a beneficial and bad effect on society and it also poses a problem to the city's management system. Hence, this article is intended to discuss the outcome of a review of a number of literature in relation to the urban sprawl overview globally, and in the context of Malaysia itself.
\end{abstract}

Keywords: - Urban Expansion, Urban Periphery, Urban Sprawl, Malaysia

\section{(c) $\$(1)$}




\section{INTRODUCTION}

The urban sprawl terminology was introduced by Earle Draper in 1937, and he is a city planner from the United States (Black, 1996). According to Ewing (1994), Ewing et al. (2003) and Tsai (2005), they divide the concept of urban sprawl into three conditions: first, low density development, and scattered everywhere to form a large city; secondly, there is a separation between the inhabitants of the population and the place where they work; and thirdly, the lack of opened space for social support functions. In view of Galster et al. (2001), Resnik (2010) and Wassmer (2008), they argue that the concept of urban sprawl is a low density land use in development involving a combination of eight things namely: density, convergence, grouping, connectivity, concentration, mixed development, neighborhood and extension. According to Brueckner and Fansler (2001), Katiman Rostam et al. (2010), Livanis et al. (2006) and McGee (2010), urban sprawl are a low-density physical form of a large urban area and extend to the periphery, usually using agricultural land for urban area expansion purposes. In fact, Peiser (2001) argues that urban sprawl should look at the urban form, land use, impact and density of development within a city. Therefore, the urban sprawl operational definition must refers to a city that evolves from a high density center to form a low density area towards its periphery based on its own phases involving the historical outbreak of a city. In fact, the outbreak of a city is not the same to the others. Hence, this article aims to discuss the outcome of a review of a number of literature in relation to the urban sprawl overview globally, and in the context of Malaysia particularly.

\section{Global Perspectives}

A common aspects found in earlier works on the concept of urban sprawl are more referring to the boundary expansion of a city. This is because each city has its own boundary expansion process and has implications for different societies. Hence, the urban sprawl in the viewpoints of the study have to look into two different worlds, namely developed and developing countries as these two parts of the world have their own pattern of development. This method is considered appropriate as Anthony (2004), Byun and Esparza (2005), Costley (2006) and Kumar et al. (2011) as each municipality of the world is different in its culture and priorities in shaping the community.

The urban areas of developed territories like the United States have experienced a disastrous situation that affected the lifestyle or value of its inhabitants. According to Lewyn (2000), in 1900 every city in the United States experienced significant population growth. Until the end of the Second World War, the number of people living in metropolitan areas reached 70 percent. In Razin's (1998) view, Razin and Rosentraub (2000) and Resnik (2010), congestion in the city and the deterioration of the value of life forced the urban community to slowly go out to the periphery to enjoy a better life. In the last 40 years, urban population has shrunk by up to 60 percent. For example, St. Louis recorded a population reduction of up to 60 per cent, Buffalo by 45 per cent and Cleveland by 45 per cent by the end of 1950 . Residents living in urban areas typically consist of immigrants migrating to seek out sustenance like in New York and Los Angelos. In 1990, 31 out of 37 big cities in the United States had poor communities below the poverty line of the country. In fact, in 1960 the city centers in the United States covered one-third of the country's poor. Such was the case in Resnik's (2010) view that it received attention from the 45th US deputy president at that time, Albert Arnold (Al) Gore, Jr. (January 20, 1993 to January 20, 2001) and a group of environmentalists. He criticized the incidence of urban disasters because of various problems such as weakening fundamentals, financial problems due to increased transportation costs, rising family ties and so on the lifestyle of the community problems.

According to Couch et al. (2005), in the 1980s Britain had an average build-up rate of up to 38 per cent and increased to 55 per cent in 2000. The city's boom is a government policy impact that targets urban growth of up to 60 per cent. Consequently, the cities of the southwestern United Kingdom which were once industrial zones were used as housing to accommodate the demands of urban dwellers. In fact, in 1960 until the early 1970s many new areas were opened from squat settlements. The opening of a new area for housing was done as in Liverpool making the government target 60 per cent urban development including housing reached in 2001. However, around 2001 also saw more than 90 percent of new housing built and occupied by urban dwellers. This implies that, the high demand for housing makes a city scattered to the outskirts of the city center to make the city more engaged. The problem of the town's overtaking problems has been gaining attention from the government as it has caused problems in the urban management system, the eradication of agricultural lands and the deterioration of society due to social problems, lost employment, environmental problems and various neighborhood issues.

For developing countries, there is also no lag in urban sprawl such as India, China and Malaysia. In India, the rapid development process is contributed by the business and industrial sectors. According to Dutta (2012), census reports in India found that rapid development took place was beyond the real expectations of nation-building projections. Since independence in India since 1947 until 2001, the number of urban dwellers was 377 million and in 2011 increased by 27.81 percent. The increase in population either naturally or from outside the area causes the city to be so crowded, the development is widespread and the urban outburst widens. In view of Kumar et al. (2011) it has created many problems in urban management systems such as lack of infrastructure, lack of space, economic opportunities, property ownership and other community needs. For example, in Uttar Pradesh has experienced land degradation, loss of forest, lack of basic facilities and the use of environmentally sensitive spaces. Such issues are an issue that needs to be addressed as the urban outbursts can cause the deterioration of community values and various related matters.

Similarly with China, Ke et al. (2009) and Tong et al. (2010) argues that China's economy in 1979 to 2004 has maintained its growth of 10 percent annually contributed by various sectors within the city. The rapid growth in the economy and followed by the physical city itself has resulted in soaring land use up to three times over three decades. Land development grew from 1984 to $8,842 \mathrm{sq} \mathrm{km}$ for 295 cities to 23,943 sq km for 287 cities in 2004 . Although there are areas that are not suitable for settlement, however, the urban sprawl finally creates a security, identity and environment problem for every 
city involved. Increasingly serious matter when demand for housing is rising which forces the government to provide urban space for community dwellings. The city's boom has witnessed numerous problems related to the lives of the people. For example, in terms of comfort, job opportunities that shrink in certain sectors (such as agriculture and livestock), neighborhood problems and so on are related to the lifestyle of urban dwellers.

\section{Urban Sprawl Perspectives in Malaysia}

The development of cities in Malaysia also has its own history and the intentions of the city as well as philosophy are similar to other developed countries, namely to meet the need for population growth and the rapid development of urban land use. According to Abdul Samad Hadi (2010) and Abdul Samad Hadi et al. (2009), the urbanization process in Malaysia can be divided into three phases, namely the initial city (nascent), the pseudo-township and the mega-township. This early urban phase emphasizes on the establishment of small towns to support local economic growth in the form of tin, plantation, community needs and the English administrative center. The famous City State in the era such as Melaka was not created as the basis of developing society, but rather to the government's administration and to play a role in foreign relations. According to Khoo Kay Kim (1972), the community consists only of farmers, fishermen, farm workers and miners who live habitually on the banks of the river. Thus, this early-stage municipality is more than triggering the existence of a serviceshaped city rather than exposing the urban sprawl.

According to Abdul Samad Hadi (2010), the urban situation is changing as it enters the second phase of the municipality known as pseudo or occurs after the Second World War (1947-1970). After Japan retreated from Malaya, the British government regained control of the administration by designing and implementing a better city management system. Beginning from the Japanese period, the British government established a tin and rubber processing plant to develop Malaya and cities began to grow slowly. Residents are also portrayed in various sectors of employment such as government administration, manufacturing, farm laborers, miners, fishermen, farmers, traders and others. Hence, the socio-economic of multi-racial societies will be more focused on a sector or specialization based on the economy. The pseudosal impact of the city has sparked cities outside Kuala Lumpur like Petaling Jaya in the 1950s and along the road connecting Port Klang around the 1960s and early 1970s.

Similarly, cities for other states, apart from the Klang Valley area, have their own history based on the arrangements determined by the British interests at that time of administration. However, the city of Johor Bahru looks different because the role of the king in the English colonial period is a matter of friendship, which eventually the state is not colonized just like any other states in Malaya. Most of Johor's prosperity can be seen directly through the success of Sultan Abu Bakar. He tried to persuade British and Chinese entrepreneurs to invest in agriculture. In fact, he showed a high tendency in the government's planning system so that the state was synonymous with the services he donated. In fact, the city of Johor Bahru is growing and growing after the United Malays National Organization (UMNO) was established in 1946 with various development programs implemented in line with the principle of consciousness of developing nations and country. The third phase in the opinion of Abdul Samad Hadi (2010) is the emergence of a megatownship area around the 1970s to date. Beginning in this decade, country development was well organized throughout the country, primarily through the New Economic Policy (NEP) in 1970. This policy emphasized on national unity through two-pronged points of eradicating poverty and restructuring the socio-economic of all races in order to establish a stable country, harmonious and advanced. In fact, the economic development and community development enjoyed today are among the services contributed by the NEP. As a result of this policy, the birth of the manufacturing, services, construction, and so on industry has been widespread in development compared to the first and second phases.

Cities across the country are expanding to accommodate the rapid economic growth, population growth, housing demand and business needs to meet the demands of the people. The urban sprawl occurs in a variety of circumstances either corridor by transport route, provincial corridor, city size expansion, opening of a new city that is merged with existing city and so on. The same happened to Johor Bahru City, starting from a small town as the state government and capital city administration on January 1, 1896, expanded into a Town Council in 1950. Subsequently, in April 1977 was appointed Municipal Council of Johor Bahru and until 1 In January 1994, it was appointed as the City Council of Johor Bahru because of his function being no longer just an administrative city.

\section{Conclusions}

Based on the discussion of urban sprawl through several cities in the context of developed and developing countries, it appears to have a negative impact on the lives of the people. According to Atkinson and Oleson (1996), Bier (2001), Cinyabuguma and McConnell (2013), Hortas-Rico and Sole-Olle (2010) and Ding and Bingham (2000), the end of the urban sprawl is transportation system efficiency, basic amenities, social control, ecosystem destruction, flood events, air pollution, water pollution and so on. As such, Daniels (2001) and Goetz (2013) suggest that studies related to the impacts of urban life should be taken as this aspect is important in determining the harmony of the lives of the people following the urban sprawl.

\section{References}

[1].Abdul Samad Hadi. (2010). Urbanisasi di Malaysia: mengaitkan kepelbagaian proses ke bentuk perbandaran. Malaysian Journal of Environmental Management 11(2), 21-31.

[2].Abdul Samad Hadi, Shaharudin Idrus, Abdul Hadi Harman Shah \& Ahmad Fariz Mohamed. (2009). Malaysian urbanization transition: from nascent, pseudo to livable mega-urban region. International Symposium on Sustainable 
Living: Articulating the Faces of Urbanization. Institut Alam Sekitar dan Pembangunan (LESTARI), Universiti Kebangsaan Malaysia pada 4 Jun, bertempat di Seremban, Negeri Sembilan.

[3].Anthony, J. (2004). Do state growth management regulations reduce sprawl? Urban Affairs Review 39(3), $376-397$.

[4].Atkinson, G. \& Oleson, T. (1996). Urban sprawl as a path dependent process. Journal of Economic Issues 2, 609615.

[5].Bier, T. (2001). Urban sprawl and decline: prospects for change. Public Works Management Policy 6(2), 83-87.

[6].Black, J.T. (1996). The economics of sprawl. Urban Land 55(3), 52-53.

[7].Brueckner, J.K. \& Fansler, D.A. (2001). The economics of urban sprawl: theory and evidence on the spatial sizes of cities. In, The Review of Economics and Statistics, hlm. 479-482. New York: MIT Press.

[8].Byun, P. \& Esparza, A.X. (2005). A revisionist model of suburbanization and sprawl: the role of political fragmentation, growth control and spillovers. Journal of Planning Education and Research 24, 252-264.

[9].Cinyabuguma, M. \& McConnell, V. (2013). Urban growth externalities and neighbourhood incentives: another cause of urban sprawl? Journal of Regional Science 53(2), 332-348.

[10]. Costley, D. (2006). Master planned communities: do they offer a solution to urban sprawl or a vehicle for seclusion of the more affluent consumers in Australia? Housing, Theory and Society 23(3), 157-175.

[11]. Couch, C., Karecha, J., Nuissl, H. \& Rink, D. (2005). Decline and sprawl: an evolving type of urban developmentobserved in Liverpool and Leipzig. European Planning Studies 13(1), 117-136.

[12]. Daniels, T.L. (2001). Coordinating opposite approaches to managing urban growth and curbing sprawl: a synthesis. American Journal of Economics and Sociology 60(1), 229243.

[13]. Ding, C. \& Bingham, R.D. (2000). Beyond edge cities: job decentralization and urban sprawl. Urban Affairs Review 35(6), 837-855.

[14]. Dutta, V. (2012). Land use dynamics and peri-urban growth characteristics: reflections on master plan and urban suitability from a sprawling North Indian City. Environment and Urbanization Asia 3(2), 277-301.

[15]. Ewing, R. H. (1994). Characteristics, causes and effects of urban sprawl: a literature review. Environmental and Urban Issues 15(Winter), 1-15.

[16]. Ewing, R.H., Schieber, R.A. \& Zegeer, C.V. (2003). Urban sprawl as a risk factor in motor vehicle occupant and pedestrian fatalities. American Journal of Public Health 93(9), 1541-1545.

[17]. Galster, G., Hanson, R., Ratcliffe, M.R., Wolman, H., Coleman, S. \& Freihage, J. (2001). Wrestling sprawl to the ground: defining and measuring an elusive concept. Housing Policy Debate 12, 681-717.

[18]. Goetz, A. (2013). Suburban sprawl on urban centres: tensions and contradictions of smart growth approaches in Denver, Colorado. Urban Stud 50(11), 2178-2195.

[19]. Hortas-Rico, M. \& Sole-Olle, A. (2010). Does urban sprawl increase the costs of providing local public services? Evidence from Spanish Municipalities. Urban Stud 47(7), 15131540.

[20]. Katiman Rostam, Mochamad Rosul, Er Ah Choy, Abdul Rahim Mohd Nor, Zaini Sakawi, Norazuan Md Hashim \& Aishah @ Esah Muhammad. (2010). Perbandaran dan rebakan bandar di pinggir Wilayah Metropolitan KlangLangat. Geografia: Malaysian Journal of Society and Spaces 6(2), 37-50.

[21]. Ke, S., Song, Y. \& He, M. (2009). Determinants of urban spatial scale: Chinese cities in transition. Urban Stud 46(13), 2795-2813.

[22]. Khoo Kay Kim. (1972). The Western Malay States 1850-1873: the effects of commercial development on Malay politics. Kuala Lumpur: Oxford University Press.

[23]. Kumar, A., Pandey, A.C., Hoda, N. \& Jeyaseelan, A.T. (2011). Evaluation of urban sprawl pattern in the tribaldominated cities of Jharkhand State, India. International Journal of Remote Sensing 32(22), 7651-7675.

[24]. Lewyn, M. (2000). Why sprawl is a conservative issue. Bulletin of Science, Technology and Society 20(4), 295-315.

[25]. Livanis, G., Moss, C.B., Breneman, V.E. \& Nehring, R. (2006). Urban sprawl and farmland prices. Amer. J. Agr. Econ. 88(4), 915-929.

[26]. McGee, T.G. (2010). Building liveable cities in Asia in the twenty-first century research policy challenges for the urban future of Asia. Malaysian Journal of Environmental Management 11(1), 14-28.

[27]. Peiser, R.B. (2001). Decomposing urban sprawl. Town Planning Review 72(3), 275-298.

[28]. Razin, E. (1998). Policies to control urban sprawl: planning regulations or changes in the rules of the game? Urban Studies 35(2), 321-340.

[29]. Razin, E. \& Rosentraub, M. (2000). Are fragmentation and sprawl interlinked? North American evidence. Urban Affairs Review 35(6), 821-836.

[30]. Resnik, D.B. (2010). Urban sprawl, smart growth and deliberative democracy. Public Health 100, $1852-1856$.

[31]. Tong, X., Zhang, X. \& Liu, M. (2010). Detection of urban sprawl using genetic algorithmevolved artificial neural network classification in remote sensing: a case study in Jiading and Putuo Districts pf Shanghai, China. International Journal of Remote Sensing 31(6), 1485-1504.

[32]. Tsai, Y-H. (2005). Quantifying urban form: compactness versus sprawl. Urban Stud 42(1), 141-161.

[33]. Wassmer, R.W. (2008). Causes of urban sprawl in the United States: auto reliance as compared to natural evolution, flight from bright and local revenue reliance. Journal of Policy Analysis and Management 27(3), 536-555. 